\title{
Relokasi Recloser Dengan Metode Section Technique Pada Jaringan Distribusi 20 kV
}

\author{
Yogi Darul Fadli'; Samsurizal' \\ 1,2 Teknik Elektro, Institut Teknologi PLN \\ ${ }^{2}$ samsurizal@itpln.ac.id
}

\begin{abstract}
The distribution network is the part of the electric power system that is closest to the customer. The reliability of each component of the distribution system equipment can affect the continuity of power service. This study aims to evaluate the reliability of the distribution system at the Citarik Feeder and to improve the system reliability index. The method used is the section technique method and the reliability index values for the Citarik Feeder are obtained, namely SAIFI 1.08958323 faults per customer.year, SAIDI 12.9958323 hours per customer.year. Calculations using ETAP existing conditions, Citarik Feeder SAIFI 1.0679 faults per customer.year, SAIDI 12.9629 hours per customer.year. To increase reliability, a recloser was implemented on the feeder and the most optimal reliability index was obtained, namely, Citarik Feeder SAIFI 0.9885 faults per customer.year, SAIDI 12.8447 hours per customer.year
\end{abstract}

Keywords: Reliability, Section Technique, Recloser, SAIFI, SAIDI

\begin{abstract}
ABSTRAK
Jaringan distribusi merupakan bagian sistem tenaga listrik yang berada paling dekat dengan pelanggan. Keandalan setiap komponen peralatan sistem distribusi dapat mempengaruhi kontinuitas pelayanan daya. Penelitian ini bertujuan untuk mengevaluasi keandalan sistem distribusi pada Penyulang Citarik serta meningkatkan indeks keandalan sistem. Metode yang digunakan yaitu metode section technique dan diperoleh nilai indeks keandalan untuk Penyulang Citarik yaitu, SAIFI 1,08958323 fault per customer.year, SAIDI 12,9958323 hours per customer.year. Perhitungan menggunakan ETAP kondisi eksisting, Penyulang Citarik SAIFI 1,0679 fault per customer.year, SAIDI 12,9629 hours per customer.year. Untuk meningkatkan keandalan dilakukan implementasi recloser pada penyulang dan diperoleh indeks keandalan paling optimal yaitu, Penyulang Citarik SAIFI 0,9885 fault per customer.year, SAIDI 12,8447 hours per customer.year
\end{abstract}

Kata kunci: Keandalan, Section Technique, Recloser, SAIFI, SAIDI 


\section{PENDAHULUAN}

Listrik adalah salah satu peranan penting dalam kehidupan manusia. Semakin banyak industri dan perusahaan yang berkembang, dan mereka menuntut PLN dalam penyediaan tenaga listrik harus dapat diandalkan, murah dan ekonomis.[1] Jarak antara pembangkit dengan pengguna sangat jauh, sehingga pendistribusian daya dilakukan melalui jalur transmisi / distribusi yang panjang, biasanya dalam bentuk saluran terbuka yang lebih besar kemungkinannya terjadi gangguan pada sistem kelistrikan. Gangguan ini, jika tidak dihentikan, akan menyebabkan arus interferensi yang cukup besar dan dapat mengganggu distribusi daya ke pengguna. [2]

Semakin tinggi frekuensi kerusakan jaringan distribusi, semakin buruk kualitas distribusi daya. Jaringan distribusi merupakan bagian dari berbagai macam sistem tenaga dan memiliki kejadian interferensi paling banyak dibandingkan dengan jaringan transmisi.[3] Sistem proteksi jaringan distribusi sebagian dipasang pada GI (gardu induk) dan sebagian lagi pada saluran distribusi. Untuk meminimalkan dampak interferensi pada pelanggan, semua perangkat keselamatan harus selektif dan andal. Selain untuk menghindari kerusakan akibat interferensi, tindakan proteksi selektif juga akan meningkatkan indeks kehandalan sistem distribusi / mengurangi SAIDI (System Average Interruption Duration Index) dan SAIFI (System Average Interruption Frequency Index).[4]

Tingkat kehandalan jaringan distribusi biasanya diukur dengan dua parameter, yaitu: SAIDI dan SAIFI bilamana SAIFI dan SAIDI, semakin rendah tingkat keandalan dan layanannya. Salah satu cara untuk meningkatkan keandalan jaringan distribusi menurut indeks keandalan adalah dengan memasang recloser.[5] Recloser adalah alat pengaman yang dapat mendeteksi arus berlebih yang disebabkan oleh korsleting antara fasa atau antara fasa dan ground. Recloser memotong arus dan secara otomatis mati pada interval yang dapat diatur sesuai dengan pengaturan interval recloser..[5]

Recloser pada penyulang citarik dirasa kurang efektif ditempatkan dipangkal saluran, karena jika terjadi sebuah gangguan maka satu penyulang tersebut akan terkena dampaknya atau trip satu penyulang, oleh karena itu dilakukanlah relokasi penempatan recloser yang diharapkan dapat berfungsi untuk melokalisir daerah gangguan dan juga dapat menurunkan angka SAIDI dan SAIFI.

Metode yang digunakan dalam menentukan nilai indeks keandalan pada penyulang Citarik yaitu dengan menggunakan metode Section Technique, yang mana dengan menggunakan metode ini nantinya pada penyulang Citarik akan dipisah menjadi beberapa Section atau bagian dengan membatasinya oleh LBS (Load Break Switch). Dengan menggunakannya metode Section Technique ini nantinya akan didapatkan nilai SAIDI dan SAIFI per titik beban (Load Point) dan nilai SAIDI dan SAIFI pada sistem jaringan distribusi penyulang Citarik. Nilai keandalan yang dihasilkan sebelum dilakukannya relokasi recloser dengan menggunakan metode Section Technique ini nantinya akan dibandingkan nilai keandalannya setelah melakukan relokasi penempatan recloser dengan menggunakan simulasi software ETAP 16 pada penyulang Citarik.

\section{METODE/PERANCANGAN PENELITIAN}

Penelitian ini dilakukan pada bulan Februari - Mei 2021 bertempat di PT.PLN (Persero) UP3 Depok. Penelitian ini menggunakan data PT.PLN (Persero) UP3 Depok Jenis data yang diperoleh adalah data single line diagram Penyulang Citarik, data panjang saluran, jumlah pelanggan di Penyulang Citarik, dan data kapasitas trafo pada Penyulang 
Citarik. Alur proses penelitian menggunakan metode section technique adalah sebagai berikut:

1. Membagi suatu topologi jaringan yang berupa one-line diagram menjadi sectionsection berdasarkan jumlah segmentation device.

2. Memasukan data panjang saluran part, data jumlah pelanggan tiap titik beban dan data keandalan.

3. Mengevaluasi suatu mode kegagalan.

4. Mengevaluasi waktu pemadaman dan waktu pemindahan.

5. Menghitung frekuensi kegagalan dan durasi gangguan terhadap tiap titik beban.

6. Mengalikan frekuensi kegagalan $\lambda T B$ dan durasi UTB pada setiap titik beban dengan jumlah pelanggan setiap titik beban kemudian membaginya dengan jumlah total pelanggan satu system.

7. Mengalikan frekuensi kegagalan $\lambda T B$ dan durasi UTB pada setiap titik beban dengan jumlah pelanggan setiap titik beban kemudian membaginya dengan jumlah total pelanggan satu system.

8. Mengevaluasi indeks keandalan setiap section dengan menjumlahkan indeks keandalan setiap titik beban.

9. Mengevaluasi indeks keandalan system dengan menjumlahkan indeks keandalan setiap part.

Perancangan dimaksudkan untuk menentukan posisi optimal penempatan recloser pada Penyulang Citarik. Adapun fungsi tujuan dari perancangan ini adalah menurunkan nilai SAIDI dan SAIFI Penyulang Citarik. Batasan-batasan penelitian ini adalah data pelanggan pada Penyulang Citarik sebelum dan sesudah reposisi berbeda, simulasi program menggunakan program ETAP 16, Hanya menentukan posisi penempatan recloser yang paling optimal, dan kondisi keandalan penyulang setelah reposisi.

Perancangan ini hanya menentukan 3 letak recloser yang optimum dengan kandidat hasil yang menunjukkan nilai SAIDI dan SAIFI terkecil pada program ETAP 16 yang merupakan penempatan recloser yang optimal.

Alur penelitian dapat digambarkan dengan diagram alir pada gambar 2 di bawah:

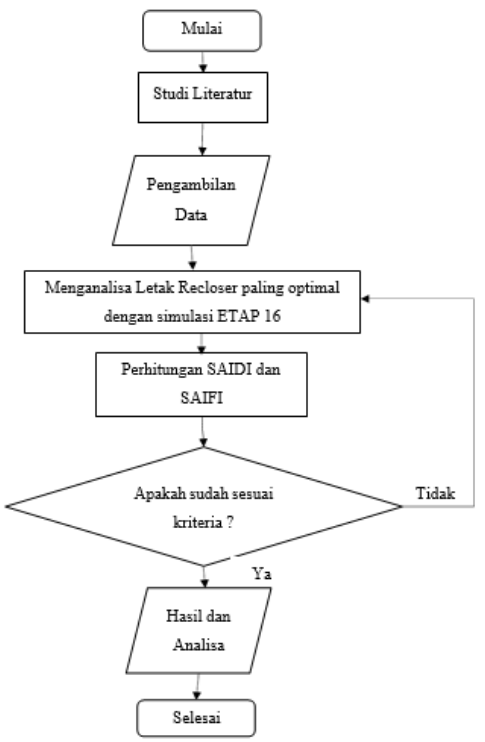

Gambar 1. Diagram alir 


\subsection{Keandalan Sistem Distribusi Tenaga Listrik}

Konsep keandalan aplikasi sistem distribusi berbeda dengan aplikasi sistem pembangkitan dan aplikasi sistem transmisi. Sistem distribusi lebih berorientasi pada titik beban pelanggan daripada wujud sistem. Sistem distribusi lokal lebih diperhitungkan daripada sistem terintegrasi secara luas dalam ruang lingkup fasilitas pembangkitan dan transmisi. Keandalan sistem pembangkitan dan transmisi lebih mempertimbangkan probabilitas hilangnya beban (loss of load), dengan lebih sedikit melihat komponen sistem, sedangkan keandalan distribusi melihat ke semua aspek dari teknik, seperti desain, perencanaan, pengoperasian. Sistem pembangkitan dan transmisi yang terintegrasi lebih kompleks dari sistem distribusi, sedangkan perhitungan probabilitas metematiknya lebih sederhana dibandingkan yang dibutuhkan untuk penaksiran keandalan pembangkitan dan transmisi [1].

\subsection{Indeks Keandalan}

Indeks keandalan yang dievaluasi menggunakan konsep klasik yaitu menghitung laju kegagalan rata-rata $(\lambda)$, durasi pemadaman rata-rata $(r)$, dan ketidaktersediaan tahunan rata-rata $(U)$. Indeks keandalan adalah suatu besaran probabilitas yang menyatakan indikator keandalan.

Keandalan dari pelayanan konsumen dapat dinyatakan dalam beberapa indeks yang biasanya digunakan untuk mengukur keandalan dari suatu sistem. Adapun indeks tersebut, antara lain:

1. System Average Interuption Frequency Index (SAIFI) dapat didefinisikan sebagai jumlah rata-rata kegagalan yang terjadi per pelanggan yang dilayani oleh sistem per satuan waktu (umumnya per tahun). Perhitungan dengan metode Section Technique dimulai dengan menghitung SAIFI per load point menggunakan persamaan berikut :

$$
\text { SAIFI }=\frac{\Sigma N T B \times \lambda T B}{\Sigma N}
$$

Keterangan :

NTB : jumlah pelanggan di titik pemuatan $\mathrm{N}$ : jumlah pelanggan pada sistem $\lambda T B$ : frekuensi gangguan peralatan (pemadaman/tahun)

2. System Average Interuption Duration Index (SAIDI) dapat didefinisikan sebagai nilai rata-rata dari lamanya kegagalan untuk setiap konsumen selama satu tahun. Perhitungan dengan metode Section Technique dimulai dengan menghitung SAIDI per load point menggunakan persamaan berikut:

$$
\text { SAIDI }=\frac{\Sigma N T B \times U T B}{\Sigma N}
$$

Keterangan :

NTB : jumlah pelanggan di titik pemuatan $\mathrm{N}$ : jumlah pealnggan pada sistem UTB : durasi interferensi masing masing titik beban (jam) 
Laju kegagalan $(\lambda)$ merupakan nilai rata-rata dari jumlah kegagalan dalam satuan interval waktu. Ketidaktersediaan (U) merupakan durasi gangguan suatu sistem tenaga listrik ketika kondisi sistem tidak dapat menyuplai daya ke konsumen.

Tabel 1. Data indeks kegagalan Saluran Udara jaringan distribusi

\begin{tabular}{|l|c|}
\hline \multicolumn{2}{|c|}{ Saluran Udara } \\
\hline Sustained failure rate $(\lambda / \mathrm{km} / \mathrm{yr})$ & 0,2 \\
\hline Momentary failure rate $(\mathrm{Nkm} / \mathrm{yr})$ & 0,003 \\
\hline r (repair time) (jam) & 10 \\
\hline rs (switching time) (jam) & 0,15 \\
\hline
\end{tabular}

Tabel 2. Data indeks kegagalan peralatan jaringan distribusi

\begin{tabular}{|l|c|lr|ll|}
\hline Komponen & (failure rate) & $\begin{array}{l}\text { r (repair time) } \\
\text { (jam) }\end{array}$ & $\begin{array}{l}\text { rs (switching time) } \\
\text { (jam) }\end{array}$ \\
\hline Trafo Distribusi & $0,005 /$ unit/thn & 10 & 0,15 \\
\hline Circuit Breaker & $0,004 /$ unit/thn & 10 & 0,15 \\
\hline $\begin{array}{l}\text { Load Break } \\
\text { Switch }\end{array}$ & $0,003 /$ unit/thn & 10 & 0,15 \\
\hline
\end{tabular}

Parameter $\lambda$ dan $U$ akan dipergunakan dalam menghitung nilai keandalan pada setiap peralatan yang terdapat pada jaringan distribusi. Adapun perhitungan $\lambda$ dan $U$ pada setiap titik load point adalah sebagai berikut:

1. Failure rate load point ( $\left.\lambda_{\mathrm{LP}}\right)$ adalah nilai dari penjumlahan $\lambda$ setiap peralatan sistem tenaga listrik yang ada pada jaringan distribusi seperti recloser, circuit breaker, trafo distribusi yang merupakan alat-alat yang mempengaruhi titik beban yang akan dihitung.

2. Ketidaktersediaan (U) load point (ULP) adalah suatu nilai dari perkalian antara $\lambda$ dengan $r$ masing-masing peralatan yang nantinya akan mempengaruhi titik beban yang dihitung.

\subsection{Recloser}

Recloser merupakan rangkaian yang terdiri dari pemutus arus yang dilengkapi dengan kotak kontrol elektronik. Kotak distribusi adalah alat elektronik yang digunakan sebagai alat penutup. Alat ini tidak ada hubungannya dengan tegangan menengah.Pada alat ini recloser dapat dikendalikan dengan cara melepaskan. Recloser ini mirip dengan Circuit Breaker dan juga digunakan pada noise splitter karena terletak di saluran distribusi. Recloser dan perangkat kontrol berada di kutub yang sama. Sebagai perangkat proteksi arus berlebih, ia memiliki berbagai fungsi tambahan, seperti label hotline, gangguan ground sensitif, dll.

Fungsi dari recloser adalah untuk dengan cepat memisahkan area atau jaringan yang diganggu oleh sistem, sehingga dapat mengurangi area interferensi seminimal mungkin untuk sementara hingga gangguan tersebut dianggap tidak ada, sehingga PBO akan menutup kembali sesuai dengan pengaturannya sehingga jaringannya akan aktif secara otomatis. 


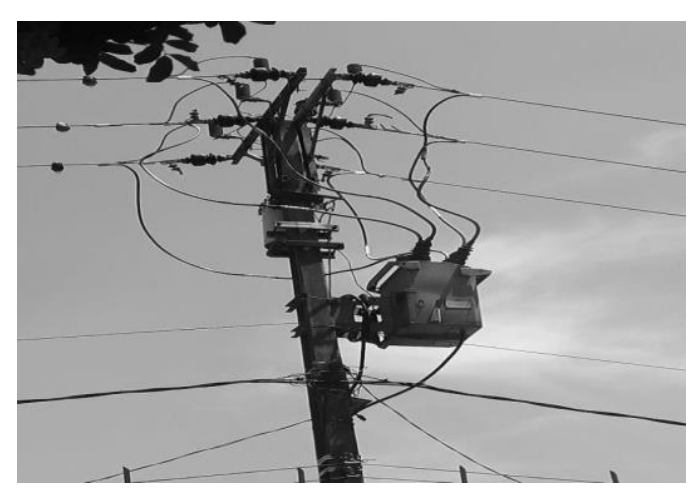

Gambar 2. Recloser Pada Jaringan Distribusi

\subsection{Section Technique}

Metode Section Technique ini merupakan suatu metode yang dalam menentukan nilai indek keandalannya secara terstruktur dalam melakukan analisa suatu sistem jaringan distribusi. Metode ini dalam melakukan suatu analisa sistem berdasarkan pada bagaimana suatu kegagalan dari peralatan peralatan yang mempengaruhi sebuah operasi sistem. Efek dari kegagalan suatu peralatan perlatan tersebut kemudian di analisis pada semua titik beban (load point).

\section{HASIL DAN PEMBAHASAN}

Penyulang Citarik merupakan penyulang yang berada di Kota Depok. Penyulang ini melayani suplai energi listrik untuk wilayah Cibinong, tepatnya pada Jalan Raya Pabuaran hingga ke Jalan kp Cilangkap. Penyulang Citarik menggunakan sistem jaringan radial dengan sumber listrik dari penyulang ini berasal dari trafo II GI Cimanggis dengan kapasitas 60 MVA. Penyulang ini memiliki 50 buah trafo distribusi, dengan total daya yang terpasang adalah sebesar 11.130 kVA. Panjang saluran pada Penyulang Citarik adalah sepanjang $29,083 \mathrm{kms}$, dengan total jumlah pelanggan pada Penyulang Citarik adalah sebanyak 11.283 pelanggan.

\subsection{Analisa Dan Perhitungan Indeks Keandalan Sistem Distribusi Penyulang Citarik}

Untuk menganalisis indeks keandalan pada system distribusi Penyulang Citarik. Ketika melakukan perhitungan untuk mendapatkab indeks keandalan menggunakan section technique dan juga menggunakan ETAP 16. setelah mendapatkan nilai indeks keandalan SAIFI dan SAIDI pada section technique, maka kemudian nilai indeks simulasi ETAP software, dimana standard ETAP. Maka kemudian nilai indeks simulasi pada Hasil nilai dari perbandingan tersebut dapat kita ketahui dimana selisih dan tingkat keandalan sistem distribusi disana, sehingga juga dapat digunakan sebagai tolak ukur dari perbaikan stem dimasa mendatang.

\subsection{Analisa Indeks Keandalan Sistem Distribusi Penyulang Citarik Dengan Metode Section Techniqe}

Berdasarkan data-data yang diperoleh pada kantor PLN UP3 Depok dapat penulis analisis indeks keandalan sistem distribusi penyulang citarik dapat digunakan data panjang line dan data jumlah pelanggan per titik beban. Standard yang digunakan dalam perhitungan menggunakan standard SPLN 59: 1985 untuk laju kegagalan dan waktu pemulihan peralatan system jaringan $20 \mathrm{KV}$. Berikut perhitungan indeks keandalan tiap 
penyulang. Dengan menggunakan perhitungan metode section technique, hal pertama yang dilakukan yaitu membagi penyulang menjadi beberapa part.

1. Perhitungan frekuensi kegagalan $(\lambda)$ dan lama kegagalan pada titik beban

Tabel 3. Nilai frekuensi kegagalan dan lama kegagalan titik beban section 1-4

\begin{tabular}{|l|l|l|}
\hline Load Point & $\lambda$ (gangguan/tahun) & $\begin{array}{l}U \\
\text { (jam/tahun) }\end{array}$ \\
\hline LP1-LP3 & 0,21339 & 2,1339 \\
\hline LP4-LP11 & 0,60242 & 3,0282 \\
\hline LP12-LP34 & 2,5294 & 7,6442 \\
\hline LP35-LP49 & 1,8386 & 5,5718 \\
\hline
\end{tabular}

Kita membuat contoh perhitungan SAIFI dimana titik beban 1, dengan mengkalikan jumlah konsumen NLP1 pada titik beban tersebut dengan ALP1, lalu dibagi dengan total konsumen pada section 1. Dibawah ini perhitungan indeks keandalan SAIFI pada titik beban 1 untuk section 1.

$$
\begin{aligned}
& \text { SAIFI } I_{L P 1}=\frac{N L P 1 \times \lambda L P 1}{N \text { section } 1}=\frac{223 \times 0,21339}{677}=0,070289468(\mathrm{f} / \text { customer } / \mathrm{yr}) \\
& \text { SAIDI } I_{L P 1}=\frac{N L P 1 \times \text { ULP1 }}{\text { Nsection } 1}=\frac{223 \times 2,1339}{677}=0,70289468(\mathrm{hr} / \text { customer } / \mathrm{yr})
\end{aligned}
$$

Sedangkan untuk indeks keandalan SAIDI titik beban 1 dapat diperoleh dari mengalikanjumlah konsumen LP1 yang ada pada titik beban tersebut dengan ULP1 kemudian dibagidengan total konsumen yang ada pada section 1 .

Tabel 4. Indeks keandalan sistem per section

\begin{tabular}{|l|ll|}
\hline \multirow{2}{*}{ Section } & \multicolumn{3}{|l|}{ Indeks Keandalan } \\
\cline { 2 - 3 } & $\begin{array}{l}\text { SAIFI } \\
\text { (fault/cust.yr) }\end{array}$ & $\begin{array}{l}\text { SAIDI } \\
\text { (hr/cust.yr) }\end{array}$ \\
\hline 1 & 0,14516323 & 1,4516323 \\
\hline 2 & 0,30242 & 2,0282 \\
\hline 3 & 0,3294 & 4,9442 \\
\hline 4 & 0,3126 & 4,5718 \\
\hline Total & 1,08958323 & 12,9958323 \\
\hline
\end{tabular}

Pada penyulang Citarik yang dianalisis diperoleh nilai SAIFI Sebesar 1,08958323 (f/pelanggan.thn) dan nilai SAIDI sebesar 12,9958323 (hr/pelanggan.thn).

Tabel 5. Nilai Indeks Keandalan Penyulang Citarik Metode Section Technique

\begin{tabular}{|l|l|l|}
\hline \multirow{2}{*}{ Penyulang } & \multicolumn{2}{|l|}{ Indeks Keandalan } \\
\cline { 2 - 3 } & $\begin{array}{l}\text { SAIFI } \\
\text { (fault/cust.yr) }\end{array}$ & $\begin{array}{l}\text { SAIDI (hr/cust } \\
\text { interr) }\end{array}$ \\
\hline Citarik & 1,08958323 & 12,9958323 \\
\hline
\end{tabular}

Dihitung dari metode section technique, nilai SAIFI dan SAIDI penyulang citarik dibandingkan dengan standar PLN Standar yang digunakan adalah SPLN 59 : 1985, nilai 
SAIFI 3,21 (f/customer.yr) dan SAIDI 12,8 (jam/pelanggan. ). Terlihat bahwa nilai SAIFI penyulang citarik sudah memenuhi standar dan tergolong reliable, sedangkan nilai SAIDI masih tergolong reliable dan memenuhi standar PLN.

\subsection{Pemodelan Sistem Distribusi Penyulang Citarik Pada Software ETAP 16}

Gunakan data yang dikumpulkan dari penyulang citarik dan diagram satu garis untuk menganalisis indeks keandalan sistem distribusi tenaga listrik penyulang citarik. Kemudian menggunakan software ETAP 16 untuk memodelkan kondisi operasi yang ada, dan kemudian melakukan simulasi keandalan untuk mendapatkan indikator keandalan SAIFI, SAIDI pada kondisi operasi yang ada, dan membandingkannya dengan hasil perhitungan indikator keandalan SAIFI dan SAIDI menggunakan metode section technique.

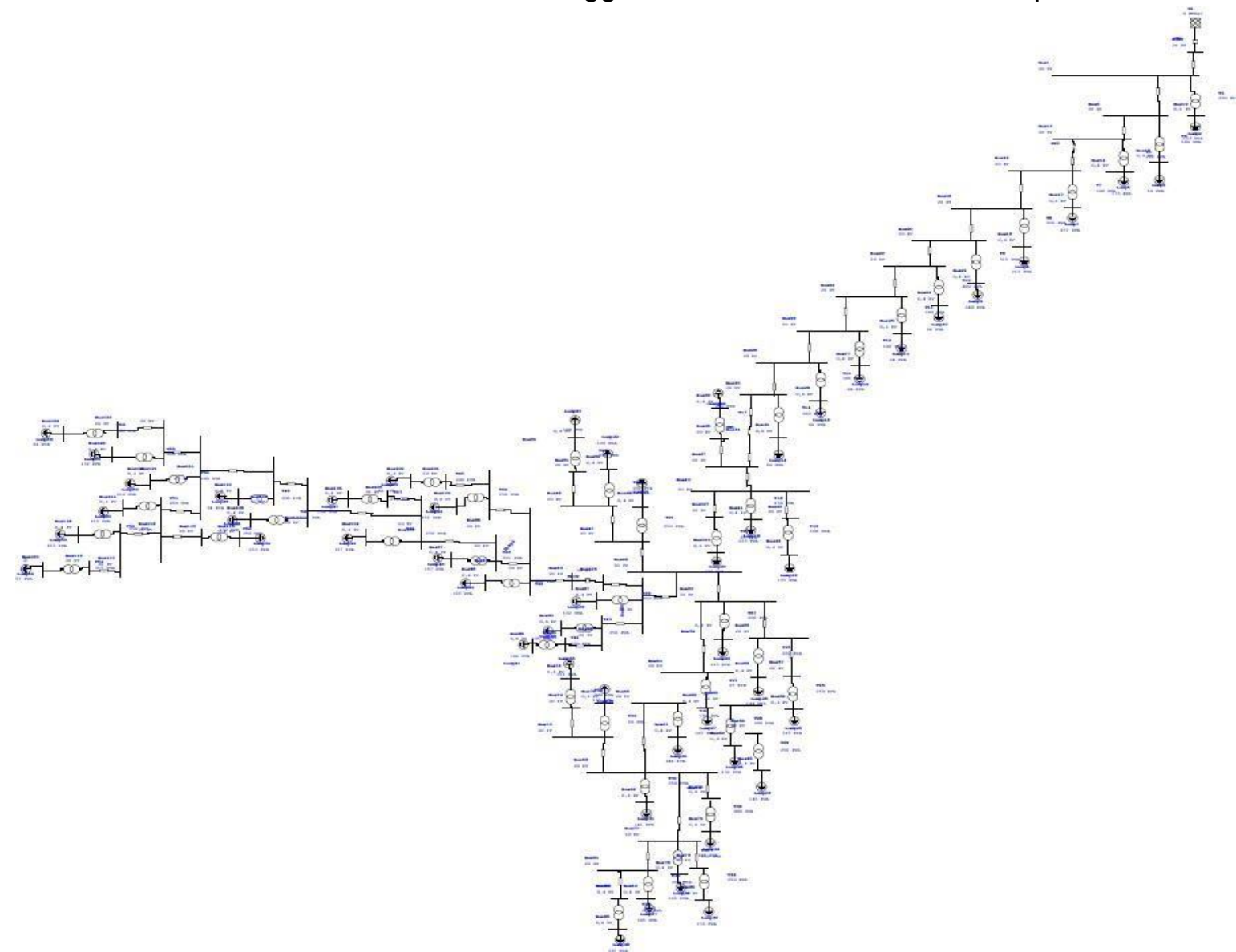

Gambar 3. Single Line Diagram Penyulang Citarik Pada ETAP

\subsection{Simulasi Keandalan Sistem Distribusi Penyulang Citarik Dengan Kondisi Eksisting}

Setelah menjalankan indeks reliabilitas pada software ETAP 16, indeks reliabilitas Penyulang Citarik SAIFI=0,9885 (f/pelanggan.thn), SAIDI=12,8447 (hr/pelanggan.thn). Untuk nilai pada software ETAP penyulang citarik SAIFI= 1,08958323 (f/pelanggan.thn), SAIDI= 12,9958323 (hr/pelanggan.thn), hasil perhitungan kedua indikator reliabilitas menunjukkan bahwa nilai SAIDI dan SAIFI adalah di penyulang citarik memenuhi standar PLN 59:1985, yaitu SAIFI=3.21 (f/pelanggan.thn) dan SAIDI=12,8 (hr/pelanggan.thn ). 
Hasil simulasi keandalan sistem pada jaringan distribusi penyulang citarik berdasarkan kondisi eksisting menggunakan software ETAP 16 dapat dilihat pada gambar dibawah ini.

$\begin{array}{lllll}\text { Project: } & \text { SKRIPSI YOGI } & \text { ETAP } & \text { Page: } & 1 \\ \text { Location: } & 16.00 \mathrm{C} & \text { Date: } & 18-07-2021 \\ \text { Contract: } & & & \text { SN: } & 4359168 \\ \text { Engineer. } & \text { YOGI DARUL FADLI } & \text { Study Case: RA } & \text { Revision: } & \text { Base } \\ \text { Filename: } & \text { SKRIPSI } & & \text { Config: } & \text { Normal }\end{array}$

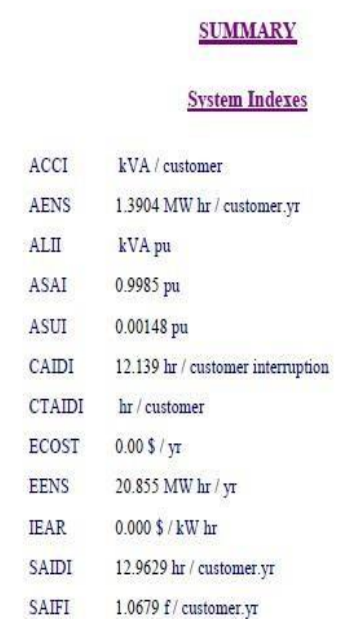

Gambar 4. Hasil Simulasi Kondisi sebelum recloser dipindahkan pada Penyulang Citarik Menggunakann ETAP

SAIFI = 1,0679 f/plnggan.thn

SAIDI $=12,9629$ hr/plnggan. thn

SAIFI $=0,9885$ f/plnggan $\cdot$ thn

SAIDI $=12,8447$ hr/plnggan. thn

\begin{tabular}{|c|c|c|c|}
\hline \multirow{3}{*}{$\begin{array}{l}\text { Project. } \\
\text { Location: } \\
\text { Contract: }\end{array}$} & \multirow[t]{2}{*}{ SKRIPSI YOGI } & \multicolumn{2}{|r|}{ ETAP } \\
\hline & & & $16.0 .0 \mathrm{c}$ \\
\hline & & & \\
\hline Engineer. & YOGI DARUL FADLI & & Study Case: RA \\
\hline Filename: & SKRIPSI & & \\
\hline & & & SUMMARY \\
\hline & & & System Inderes \\
\hline & & $\mathrm{ACCI}$ & $\mathrm{kVA} /$ customer \\
\hline & & AENS & $1.3783 \mathrm{MW} \mathrm{hr} /$ customer $y \mathrm{r}$ \\
\hline & & ALII & kVA pu \\
\hline & & ASAI & $0.9985 \mathrm{pu}$ \\
\hline & & ASUI & $0.00147 \mathrm{pu}$ \\
\hline & & CADI & $12.994 \mathrm{hr} /$ customer internuption \\
\hline & & CTADI & hr / customer \\
\hline & & ECOST & $0.00 \mathrm{~s} / \mathrm{ys}$ \\
\hline & & EENS & $20.674 \mathrm{MW} \mathrm{hr} / \mathrm{yr}$ \\
\hline & & IEAR & $0.000 \mathrm{~s} / \mathrm{kW} \mathrm{hr}$ \\
\hline & & SAIDI & $12.8447 \mathrm{hr} /$ customer.yr \\
\hline & & SAIFI & $0.9885 \mathrm{f} /$ customer $y \mathrm{t}$ \\
\hline
\end{tabular}

Gambar 5. Hasil Simulasi Kondisi sesudah recloser dipindahkan pada Penyulang Citarik Menggunakann ETAP 


\subsection{Hasil Simulasi Keandalan Penyulang Citarik Dengan Pemasangan Recloser Berdasarkan Percobaan 1 Sampai 3}

Berikut disajikan pada tabel 6. Perbandingan indeks keandalan berdasarkan percobaan 1 hinggan 3.

Tabel 6. Perbandingan Indeks Keandalan

\begin{tabular}{|c|c|c|c|}
\hline \multirow{2}{*}{ Penyulang } & Kondisi & $\begin{array}{c}\text { SAIFI } \\
\text { (fault/cust.yr) }\end{array}$ & $\begin{array}{c}\text { SAIDI } \\
\text { (hr/cust.yr) }\end{array}$ \\
\hline \multirow{4}{*}{ Citarik } & Standar PLN & 3,21 & 12,8 \\
\cline { 2 - 4 } & Perhitungan Section Technique & 1,08958323 & 12,9958323 \\
\cline { 2 - 4 } & Percobaan 1 (ETAP) & 0,9885 & 12,8447 \\
\cline { 2 - 4 } & Percobaan 2 (ETAP) & 1,0679 & 12,9629 \\
\cline { 2 - 4 } & Percobaan 3 (ETAP) & 1,0649 & 15,0934 \\
\hline
\end{tabular}

Tabel 6. adalah indeks keandalan standar PLN, perhitungan metode section technique, hasil perhitungan simulasi perangkat lunak ETAP 16 dan tabel perbandingan setelah percobaan 1 3. SAIFI dan SAIDI digunakan pada penyulang Citarik menggunakan teknologi tersegmentasi.Setelah percobaan 1 sampai 3, indeks reliabilitasnya cukup berbeda, dan setelah percobaan aplikasi, indeks reliabilitasnya turun. Oleh karena itu, dapat disimpulkan bahwa pemasangan recloser dan peralatan lainnya akan mempengaruhi keandalan sistem.

Tabel 7. Hasil Yang Di peroleh

\begin{tabular}{|c|c|c|c|}
\hline No & Kondisi & $\begin{array}{c}\text { SAIFI } \\
\text { (gangguan/thn) }\end{array}$ & $\begin{array}{c}\text { SAIDI } \\
\text { (jam/thn) }\end{array}$ \\
\hline 1 & Perhitungan Section Technique & 1,08958323 & 12,9958323 \\
\hline 2 & Percobaan 1 (ETAP) & 0,9885 & 12,8447 \\
\hline 3 & Percobaan 2 (ETAP) & 1,0679 & 12,9629 \\
\hline 4 & Percobaan 3 (ETAP) & 1,0649 & 15,0934 \\
\hline
\end{tabular}

Pada tabel 7. merupakan hasil keseluruhan yang di dapat dan pada bagian no 1 terdapat perhitungan dari metode section technique yang dimana nilai dari SAIFI= 1,0895823 (gangguan/thn) dan SAIDI=12,9958323 (jam/thn) dari hasil tersebut ternyata sudah sesuai dengan standar PLN 59:185, yaitu SAIFI= 3,21 (gangguan/thn) dan SAIDI= 12,8 (jam/thn) dan dari hasil percobaan yang pertama dan percobaan kedua ternyata nilai SAIDI dan SAIFI sudah sesuai dengan standar PLN 59:185. Tetapi pada percobaan yang ke-3 nilai dari SAIDI tidak sesuai dengan standar PLN 59:1985 dikarenakan Ketika recloser dipindahkan pada posisi yang ke-3 dan mengalami gangguan proses dari lamanya gangguan pada sistem yang mempengaruhi nilai SAIDI. Oleh sebab itu factor yang menyebabkan nilai dari SAIDI dan SAIFI tidak standar PLN 59:1985 dikarenakan penempatan recloser yang kurang optimal dan sistem dari recloser tidak berfungsi dengan baik. 


\section{KESIMPULAN DAN SARAN}

Dengan diperolehnya hasil perhitungan dan analisa dari penelitian ini, maka dapat diambil kesimpulan sebagai berikut. Dihitung dengan metode bagian section technique, indeks keandalan sampler SAIFI adalah $1.08958323 \mathrm{f} /$ customer.yr, dan SAIDI adalah 12.9958323 customer.yr. Nilai SAIFI kedua penyulang tersebut sesuai dengan standar PLN yaitu 3,21 f/customer.yr, sedangkan nilai SAIDI sesuai dengan standar yaitu 12,8 $\mathrm{hr} /$ customer.yr. Dari hasil perhitungan ETAP dengan menggunakan kondisi eksisting, indeks keandalan SAIFI Pengumpan Citarik adalah $0.9885 \mathrm{f} /$ customer.thn, dan SAIDI adalah $12.8447 \mathrm{hr} /$ customer.thn. Setelah melakukan percobaan dengan recloser pada feeder Percobaan 1-3, nilai terbaik feeder Citarik ditemukan pada Percobaan 1, dengan SAIFI sebesar $0.9885 \mathrm{f} /$ customer.yr dan SAIDI sebesar $12.8447 \mathrm{hr} /$ customer.yr.

Peranan penting pada recloser sangat membantu untuk meningkatkan indeks keandalan dan faktor ekonomi penyulang, karena penggunaan recloser dapat mengurangi atau mempercepat durasi gangguan. Seperti yang kita ketahui bersama, recloser dapat bekerja secara otomatis dan dapat diatur untuk berjalan 2 kali atau lebih ketika terjadi gangguan.

\section{DAFTAR PUSTAKA}

[1] D. Wijayanti, "Optimisasi Penempatan Recloser untuk Meminimalisir Nilai SAIDI dan SAIFI pada Penyulang PDP 04 Menggunakan Particle Swarm Optimization (PSO)," [1] S. Dhuha, "Kajian Peningkatan Keandalan Sistem Distribusi Dengan Relokasi Sectionalizer Pada Penyulang Pujon Dengan Pembangkit Terdistribusi," 2017, [Online]. Available:http://repository.ub.ac.id/id/eprint/2220.

[2] R. P. M. Simanjuntak, S. Syafriyudin, and B. Firman, "Analisis Keandalan Penempatan Recloser Dan Besar Arus Hubung Singkat Di PT. PLN (Persero) Distribusi Area Yogyakarta," J. Elektr., pp. 40-47, 2017, [Online].

[3] R. N. A. Ruwah Joto, Tresna Umar Syamsuri, "Kajian Penempatan Pole Mounted Recloser Untuk Meningkatkan Keandalan Sistem Jaringan Distribusi Di Penyulang Galunggung PT. PLN(Persero) Ulp Malang Kota," vol. 04, pp. 32-37, 2018.

[4] M. Fahrulrozi et al., "Peningkatan Keandalan Sistem Distribusi dengan Relokasi Penempatan Fuse-Recloser Optimal karena Injeksi Pembangkit Tersebar," J. EECCIS, vol. 13, no. 2, pp. 78-83, 2019, [Online]. Available: https://jurnaleeccis.ub.ac.id/.

[5] D. Ariyadi, "Optimasi Penempatan Recloser Terhadap Keandalan Pada Sistem Distribusi Di PT. PLN (Persero) Kota Subulussalam, Aceh," J. Ekon. Vol. 18, Nomor 1 Maret201, vol. 2, no. 1, pp. 41-49, 2010.

[6] W. Setiawan, W. C. Service, and Q. G. Algorithm, "Perancangan Penempatan Recloser Yang Optimum Menggunakan Metode Quantum Genetic Algorithm Di Penyulang Palapa," vol. 7, no. 4, pp. 90-99, 2020.

[7] Mohammad Rexy Hanif and Titiek Suheta, "Analisa Keandalan Sistem Distribusi 20kv di PT. PLN (Persero) Rayon Kudus Kota Menggunakan Metode Section Technique," J. Intake J. Penelit. Ilmu Tek. dan Terap., vol. 11, no. 2, pp. 56-63, 2020, doi: 10.48056/jintake.v11i2.134.

[8] I. K. Ariek Astana Adi, I. G. Dyana Arjana, and W. Setiawan, "Studi Optimasi Reposisi Recloser Untuk Meningkatkan Keandalan Pada Penyulang Blahkiuh Menggunakan 
Metode Algoritma Genetika," J. SPEKTRUM, vol. 5, no. 2, p. 272, 2018, doi: 10.24843/spektrum.2018.v05.i02.p34.

[9] M. Y. Bustomi, S. Nisworo, and D. Pravitasari, "Penempatan Recloser Menggunakan Metode Linier Programing ( Studi Kasus Feeder Sanggrahan 2 )," 2016.

[10] J. Luis da Costa, R. Sari Hartati, and W. Setiawan, "Optimasi Penempatan Recloser Untuk Memperbaiki Keandalan Pada Penyulang Lembongan Menggunakan Metode Particle Swarm Optimization-Fuzzy," J. SPEKTRUM, vol. 5, no. 2, p. 129, 2018, doi: 10.24843/spektrum.2018.v05.i02.p16. 